\title{
Development of Novel Low-Cost Activated Carbon for Carbon Dioxide Capture
}

\author{
Nor A. Rashidi, Suzana Yusup, and Azry Borhan
}

\begin{abstract}
The increase in carbon dioxide $\left(\mathrm{CO}_{2}\right)$ emission into the atmosphere has become the key factors in an extend of the temperature rise, that eventually causes global warming and climatic change. Thus, low-cost coconut shell activated carbon was synthesized, and its applicability in $\mathrm{CO}_{2}$ capture at $25^{\circ} \mathrm{C}$ and 1 bar was tested. Utilization of coconut shells as precursors for activated carbon production is economically viable. The pore structure of synthesized and commercial activated carbon was evaluated by using the nitrogen physisorption. In addition, comparability of the $\mathrm{CO}_{2}$ sorption capacity with the commercial activated carbon proposes that better-quality adsorbents can be produced by a single activation process. This chemically-free process is favorable as it promotes a cleaner pathway on the activated carbon development. Besides, the equilibrium data for $\mathrm{CO}_{2}$ adsorptions are well-fitted to Langmuir isotherm, with the maximum adsorption capacity is 49.75 and $70.42 \mathrm{~cm}^{3} / \mathrm{g}$ for both the synthesized and commercial activated carbon, respectively.
\end{abstract}

Index Terms-Activated carbon, carbon dioxide adsorption, Langmuir isotherm, waste biomass.

\section{INTRODUCTION}

The tremendous demand of energy in the world these days has caused the rising of greenhouse gases (GHG) emission, which is becoming the major concern by the public recently. Associated with that, carbon dioxide $\left(\mathrm{CO}_{2}\right)$ is labeled as the most important GHGs that contribute to the global warming through anthropogenic emission from power plant generation, transportation, and industrial sector [1]. Instead of adapting to the substantial effect of global warming, mitigation of the $\mathrm{CO}_{2}$ emission is preferable. Therefore, immediate and continuous action should be taken to decrease the $\mathrm{CO}_{2}$ concentration in the atmosphere. The $\mathrm{CO}_{2}$ reduction can be done by some options such as an enhancement in combustion and energy efficiency, reduction in the use of fossil fuel, switch to non-carbon-emitting resources i.e. renewable energy, and to capture and sequester $\mathrm{CO}_{2}$ (CCS) permanently Amongst these options, CCS is considered as a useful technique, since it provides an ample time for the development of low-cost renewable energies and cleaner usage of fossil fuels resources during the transition period [2].

Among the possible technologies for $\mathrm{CO}_{2}$ capture, solid adsorption is preferred due to low energy requirements, low capital and operating cost, together with limited secondary waste generation [3]. Activated carbon is one of the

Manuscript received July 29, 2013; revised November 24, 2013. This work was supported part by the NanoFund (NND/NA/(1)/TD11-036) Grant under Ministry of Science, Technology and Innovation (MOSTI).

The authors are with the Department of Chemical Engineering, Universiti Teknologi Petronas, Bandar Seri Iskandar, 31750, Tronoh, Perak, Malaysia (e-mail: noradilla.88@gmail.com, drsuzana_yusuf@petronas.com.my, azrybo@petronas.com.my). promising solid adsorbents that can be utilized to capture $\mathrm{CO}_{2}$ due to its numerous benefits, such as inexpensive, easy for regeneration, insensitiveness towards the moisture, high $\mathrm{CO}_{2}$ adsorption capacity at ambient condition, high specific surface area, adequate pore size distribution, high mechanical strength, as well as low in energy requirement [4]. Based on the benefits possessed by activated carbon, it has been widely employed in various applications, be it in gas or liquid phase. However, exploitation of the activated carbons in capturing $\mathrm{CO}_{2}$ has not been extensively evaluated. The potential of activated carbon in $\mathrm{CO}_{2}$ capture depends on few criteria such as types of activation method and nature of starting materials, which in turn affects the porosity and surface chemistry of the synthesized activated carbon [5]. The chemical activation method includes the ammonia treatment and impregnation technique that have been extensively employed nowadays is uninvited as it imposes hazardous impacts towards the environment and also, results in pore blockage that may possibly lessen the adsorption capacity. Plaza et al. [2] proved that impregnation of activated carbon with amine-based compounds is not a suitable approach for $\mathrm{CO}_{2}$ capture at room temperature, as it reduces the surface area and block the microporous structure that is accountable for physical adsorption process. Specifically, the impregnated activated carbon with polyethylenimine (PEI) solvents which had BET surface area of $90 \mathrm{~m}^{2} / \mathrm{g}$ can only capture $\mathrm{CO}_{2}$ up to $4.9 \mathrm{wt} \%$, as compared to virgin activated carbon that had total surface area of $1,762 \mathrm{~m}^{2} / \mathrm{g}$ and $\mathrm{CO}_{2}$ adsorption capacity of 7.3 $\mathrm{wt} \%$. In addition, an incorporation of nitrogen functionalities i.e. ammonia heat treatment as proposed by Plaza et al. [3] is not very effective as the adsorption capacity is similar as the $\mathrm{CO}_{2}$-activated carbon, which is about $9.7 \mathrm{wt} \%$. Associated with that, physical activation technique with an absence of chemicals is utilized in this study.

Conventional approach of physical or thermal activation involves two steps, which is carbonization (temperature range of $\left(400-850^{\circ} \mathrm{C}\right)$ and activation (temperature range of $600-900^{\circ} \mathrm{C}$ ) processes. However, longer time and high energy consumption of the process is undesirable from the industrial point of view. Hence, one-step activation process is proposed in the study. Matos et al. [6] verifies that this approach is undeniably the simplest and the cheapest technique to obtain the carbon materials. The overall objective of this present work is to study the efficiency of manufactured activated carbons from one-step activation in $\mathrm{CO}_{2}$ capture at ambient temperature and pressure, and its physicochemical properties.

\section{Methodology}

\section{A. Preparation of Activated Carbon}

In this study, coconut shell was utilized as starting material 
for the activated carbon production. The biomass feedstock was cleaned and oven-dried at $110^{\circ} \mathrm{C}$ for minimum of $12 \mathrm{hrs}$ to remove the excessive moisture. The dried feedstock was crushed and ground to fine particles using a Fritsch Pulverisette 25/19 cutting miller, and was sieved to particle sizes of $250 \mu \mathrm{m}$. The biomass materials were stored in a dessicator until further use. The chemical compositions of the feedstock were as tabulated in Table I. Referring to Table I, the feedstock that contains high amount of fixed carbon, and low in ash content is desirable in the activated carbon production. In addition, high volatile matter of the feedstock is significant as it contributes to large pore volume of the activated carbon.

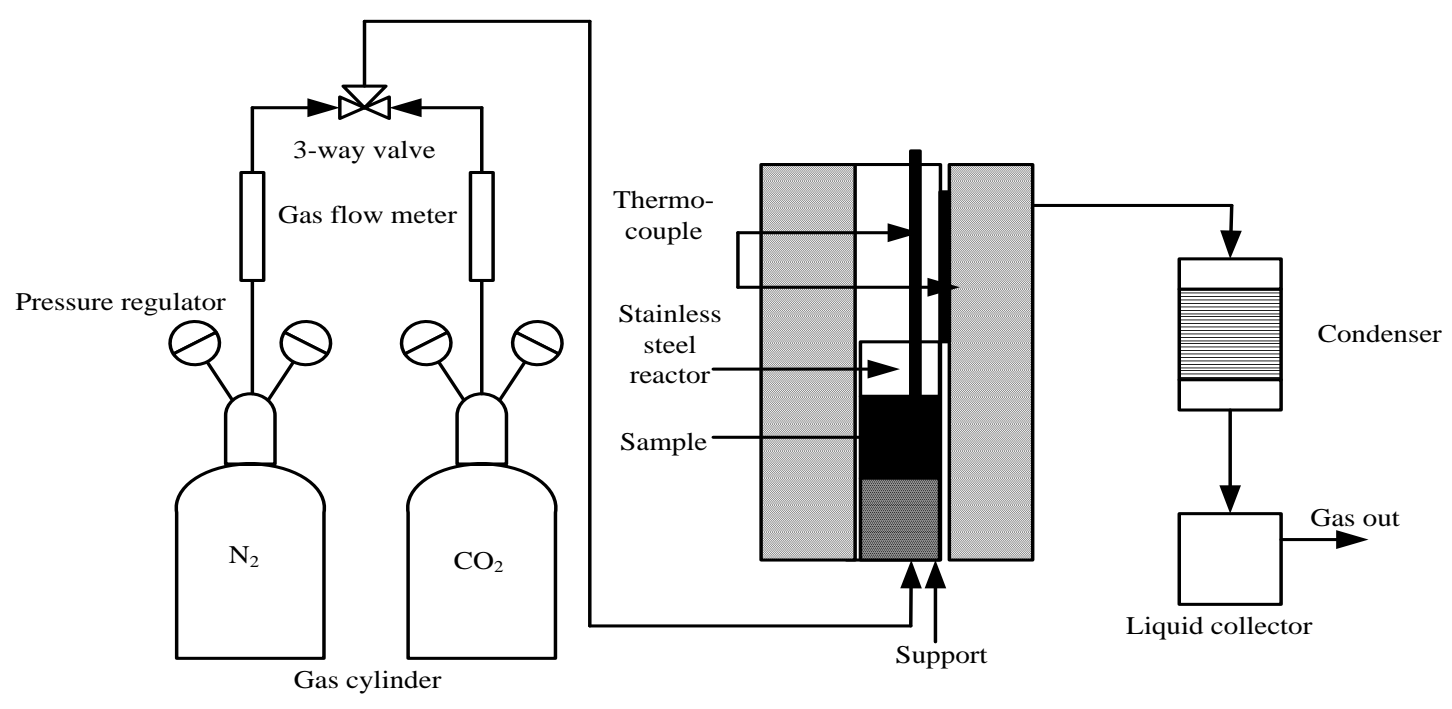

Fig. 1. Schematic diagram of experimental setup.

TABLE I: CHEMICAL COMPOSITIONS (WT\%) OF LIGNOCELLULOSIC

\begin{tabular}{|l|c|c|c|c|}
\hline Materials & Moisture & $\begin{array}{c}\text { Volatile } \\
\text { matter }\end{array}$ & Ash & $\begin{array}{c}\text { Fixed } \\
\text { Carbon }^{\mathrm{a}}\end{array}$ \\
\hline $\begin{array}{l}\text { Coconut } \\
\text { shell }\end{array}$ & 1.91 & 74.41 & 1.26 & 22.43 \\
\hline
\end{tabular}

${ }^{\mathrm{a} B y}$ differences.

\section{B. One-Step Activation Process}

The biomass feedstock was physically activated under the presence of $\mathrm{CO}_{2}$ flow in a vertical lab-scale reactor as shown in Fig. 1. The components in the experimental setup include the gas tank, reactor, thermocouple, together with the condenser. In each run, 20-30 grams of the biomass feedstock were put onto the retainer i.e. metal wire at the bottom part of sample holder, and placed into the reactor. Afterward, the reactor was flushed with nitrogen $\left(\mathrm{N}_{2} ; 99.999 \%\right.$ purity) for almost $30 \mathrm{~min}$ to ensure an inert condition prior to the experimental work. Then, one-step activation process was initiated by heating the samples to reaction temperature of $900^{\circ} \mathrm{C}$, and at heating rate of $20^{\circ} \mathrm{C} / \mathrm{min}, \mathrm{CO}_{2}$ gas $(99.98 \%$ purity) flow rate of $150 \mathrm{~cm}^{3} / \mathrm{min}$, and with residence time of $45 \mathrm{~min}$.

\section{Porosity Properties of Activated Carbon}

$\mathrm{N}_{2}$ physisorption process was carried out at $-196^{\circ} \mathrm{C}(77 \mathrm{~K})$ using a Micromeritics ASAP 2020. $\mathrm{N}_{2}$ adsorption-desorption isotherm were interpreted as a graph plot of volume of $\mathrm{N}_{2}$ gas adsorbed versus the relative pressure $\left(\mathrm{P} / \mathrm{P}_{\mathrm{o}}\right)$, in which $\mathrm{P}_{\mathrm{o}}$ was taken at an atmospheric pressure. In addition, the following parameters i.e. Brunauer-Emmett-Teller (BET) surface area, total pore volume $\left(V_{\text {total }}\right)$, total micropore volume $\left(V_{\text {micro }}\right)$ and total mesopore volume $\left(V_{\text {meso }}=V_{\text {total }}-V_{\text {micro }}\right)$, were determined. The BET surface area was estimated at $\mathrm{P} / \mathrm{P}_{\mathrm{o}}$ of
0.00 to 0.10 ; with the correlation coefficient was found to be greater than 0.999. In addition, the cross-sectional area of $\mathrm{N}_{2}$ gas was assumed to be $0.162 \mathrm{~nm}^{2}$. The total volume was calculated by converting the amount of $\mathrm{N}_{2}$ adsorbed at $\mathrm{P} / \mathrm{P}_{\mathrm{o}}$ of 0.98 , to equivalent liquid volume of the adsorbate [7]. Besides, t-plot method was used to calculate the micropore volume as well as the micropore area [8].

\section{Carbon Dioxide $\left(\mathrm{CO}_{2}\right)$ Capture}

Volumetric adsorption study of $\mathrm{CO}_{2}$ was carried out using a High Pressure Volumetric Analyzer (HPVA II). Prior of the adsorption process, $0.3-0.4 \mathrm{~g}$ samples were out-gassed in degas port at temperature of $120^{\circ} \mathrm{C}$ overnight in order to eliminate the moisture and weakly-bounded volatiles. Once the degassing process completed, the samples were cooled down to ambient temperature, and were transferred to the analysis port. $\mathrm{CO}_{2}$ adsorption was performed at room temperature $\left(25^{\circ} \mathrm{C}\right)$ and at pressure interval of $0.1 \mathrm{bar}$, until it reached to 1 bar. During this process, reaction temperature was controlled by using a re-circulating Julabo water control bath. All data requisitions were recorded in a Comprehensive Data Analysis Package via Microsoft Excel macros (v.22.0.6) software. $\mathrm{CO}_{2}$ adsorption capacity $(w t \%)$ for both the activated carbons is calculated as follows:

$$
q_{p}=\frac{V_{p} \times M W \times 100 \%}{V_{m o l, S T P}}
$$

Referring to (1), $q_{p}$ is the adsorption capacity in $\mathrm{wt} \%, V_{p}$ is volumetric adsorption capacity in $\mathrm{cm}^{3} / \mathrm{g}, \mathrm{MW}$ is adsorbate molecular weight $\left(44.01 \mathrm{~g} / \mathrm{cm}^{3}\right)$, and $V_{m o l, S T P}$ represents the 
molar volume of a gas at $\operatorname{STP}\left(22,414 \mathrm{~cm}^{3} / \mathrm{mol}\right)$.

\section{RESUlT AND DISCUSSION}

\section{A. Porosity and Surface Area Characteristics}

$\mathrm{N}_{2}$ adsorption isotherm of the prepared activated carbon with comparison to the commercial adsorbent is illustrated in Fig. 2. According to Fig. 2, volume of $\mathrm{N}_{2}$ adsorbed that is increased during the lower part of relative pressure $\left(\mathrm{P} / \mathrm{P}_{\mathrm{o}}\right)$ and tend to reach a plateau at a higher $\mathrm{P} / \mathrm{P}_{\mathrm{o}}$ indicates the filling of micropores. In addition, both the adsorbents are confirmed to demonstrate Type I BET adsorption isotherm, which belongs to microporous materials, in accordance to the International Union of Pure and Applied Chemistry classification [7], [8].

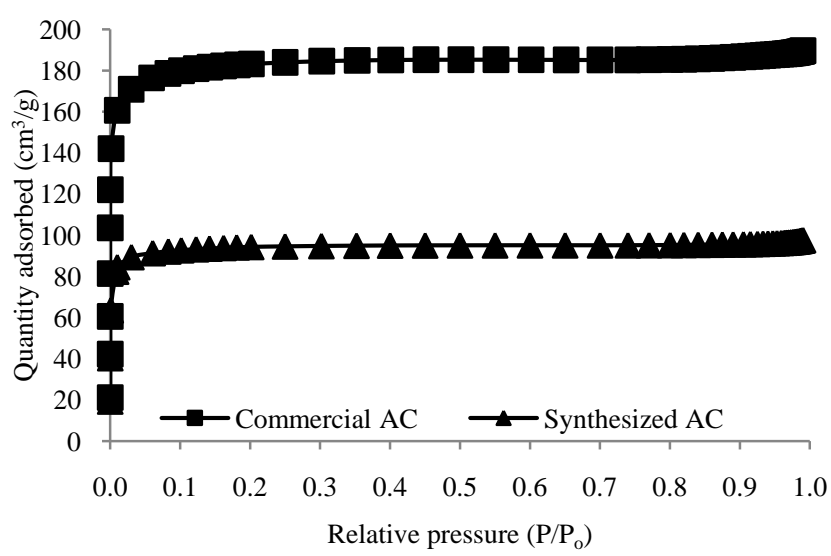

Fig. 2. $\mathrm{N}_{2}$ adsorption isotherm at $-196^{\circ} \mathrm{C}(\mathrm{AC}=$ Activated Carbon).

In addition, BET surface area, pore size and pore volume as listed in Table II can be determined from the $\mathrm{N}_{2}$ adsorption-desorption analyses. Based on Table II, the activated carbons have an average pore diameter of $1.6 \mathrm{~nm}$, which indicates their suitability to be applied in gas phase adsorption. Besides, the surface area of the raw precursors is roughly $0.96 \mathrm{~m}^{2} / \mathrm{g}$ with predominantly macropores structures. The improvement in the surface area is attributed to the $\mathrm{CO}_{2}$ activation process that will create new porosity, and simultaneously, remove the tarry products and non-carbon elements like hydrogen and oxygen. The releasing of these compounds then open the block pores, and develop the pore structure with large surface areas.

TABLE II: POROSITY AND SURFACE AREA OF SYNTHESIZED AND COMMERCIAL ACTIVATED CARBON

\begin{tabular}{|l|l|l|}
\hline Properties & $\begin{array}{l}\text { Synthesized } \\
\text { activated carbon }\end{array}$ & $\begin{array}{l}\text { Commercial } \\
\text { activated carbon }\end{array}$ \\
\hline $\begin{array}{l}\text { BET surface area } \\
\left(\mathrm{m}^{2} / \mathrm{g}\right)\end{array}$ & 370.72 & 717.22 \\
\hline $\begin{array}{l}\mathrm{t}-\mathrm{plot} \text { micropore } \\
\text { area }\left(\mathrm{m}^{2} / \mathrm{g}\right)\end{array}$ & 295.87 & 584.83 \\
\hline $\begin{array}{l}\text { Micropore } \\
\text { volume }\left(\mathrm{cm}^{3} / \mathrm{g}\right)\end{array}$ & 0.11 & 0.22 \\
\hline $\begin{array}{l}\text { Total pore } \\
\text { volume }\left(\mathrm{cm}^{3} / \mathrm{g}\right)\end{array}$ & 0.15 & 0.29 \\
\hline $\begin{array}{l}\text { Micropore } \\
\text { volume ratio }(\%)\end{array}$ & 72.67 & 74.32 \\
\hline $\begin{array}{l}\text { Average pore } \\
\text { diameter }(\mathrm{nm})\end{array}$ & 1.63 & 1.64 \\
\hline
\end{tabular}

B. Carbon Dioxide Adsorption Performance

The adsorption capacity of $\mathrm{CO}_{2}$ that is measured at room temperature and pressure is illustrated in Fig. 3. The maximum $\mathrm{CO}_{2}$ sorption capacity that is exhibited by the synthesized and commercial activated carbon is $8.21 \mathrm{wt} \%$ and $10.66 \mathrm{wt} \%$, respectively. The difference in $\mathrm{CO}_{2}$ mass uptake of these solid adsorbents could be due to the value of surface area, as shown in Table II. The commercial activated carbons that have larger BET surface area are observed to adsorb more $\mathrm{CO}_{2}$ molecules onto them, and thus, it implies that there are more surface sites for $\mathrm{CO}_{2}$ adsorption process to take place.

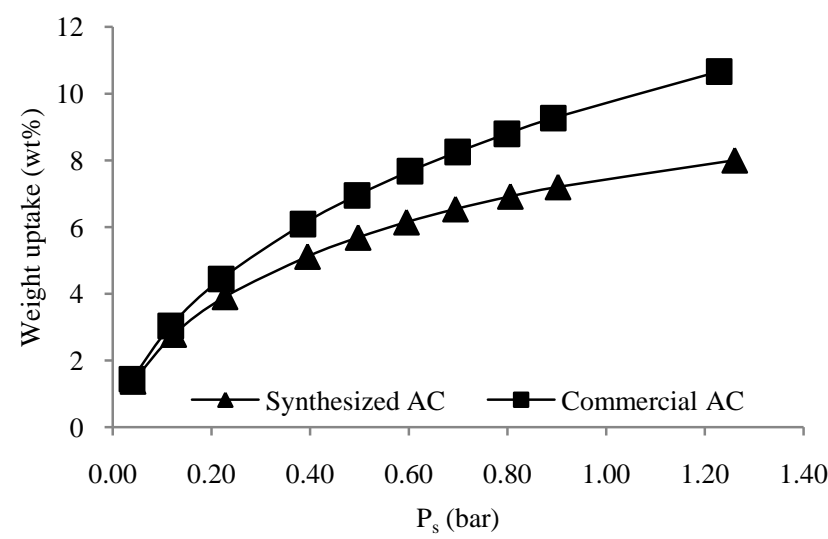

Fig. 3. Weight uptake of $\mathrm{CO}_{2}$ adsorption at $25^{\circ} \mathrm{C}(\mathrm{AC}=$ Activated Carbon $)$.

TABLE III: COMPARISON OF WEIGHT UPTAKE AT ROOM TEMPERATURE

\begin{tabular}{|c|c|c|c|c|}
\hline \multicolumn{5}{|c|}{ AND PRESSURE } \\
\hline $\begin{array}{l}\text { Sample } \\
\text { materials }\end{array}$ & $\begin{array}{l}\text { Activation } \\
\text { technique }\end{array}$ & $\begin{array}{l}\text { BET surface } \\
\text { area }\left(\mathrm{m}^{2} / \mathrm{g}\right)\end{array}$ & $\begin{array}{l}\mathrm{CO}_{2} \text { uptake } \\
(w t \%)\end{array}$ & Ref. \\
\hline $\begin{array}{l}\text { Olive stone } \\
\text { char } \\
\text { (GKOS) }\end{array}$ & $\mathrm{N}_{2}$ pyrolysis & 43 & 5.8 & \multirow{8}{*}{ [1] } \\
\hline GKOSA20 ${ }^{\mathrm{a}}$ & \multirow{3}{*}{$\begin{array}{l}\mathrm{CO}_{2} \\
\text { activation }\end{array}$} & 613 & 8.9 & \\
\hline GKOSA40 ${ }^{\mathrm{a}}$ & & 909 & 10.5 & \\
\hline GKOSA50 $^{\mathrm{a}}$ & & 1,079 & 10.7 & \\
\hline 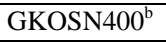 & \multirow{4}{*}{$\begin{array}{l}\text { Ammonia } \\
\left(\mathrm{NH}_{3}\right) \\
\text { treatment }\end{array}$} & 152 & 6.8 & \\
\hline${\text { GKOSN } 6000^{b}}^{b}$ & & 232 & 7.1 & \\
\hline 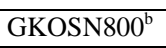 & & 390 & 8.6 & \\
\hline GKOSN900 $^{b}$ & & 442 & 7.3 & \\
\hline $\begin{array}{l}\text { Commercial } \\
\text { activated } \\
\text { carbon }(\mathrm{N})\end{array}$ & $\begin{array}{l}\mathrm{H}_{3} \mathrm{PO}_{4} \\
\text { activation }\end{array}$ & 1,762 & 7.3 & \multirow{4}{*}{ [2] } \\
\hline N-DETA $^{c}$ & \multirow{3}{*}{$\begin{array}{l}\text { Wet } \\
\text { impregnation }\end{array}$} & 157 & 4.0 & \\
\hline N-PEHA ${ }^{\mathrm{d}}$ & & 170 & 4.8 & \\
\hline $\mathrm{N}-\mathrm{PEI}^{\mathrm{e}}$ & & 90 & 4.9 & \\
\hline
\end{tabular}

${ }^{\mathrm{a}}$ GKOSA20/40/50 $=$ Represents $\mathrm{CO}_{2}$ activation at different burn-off degrees (\%).

${ }^{\mathrm{b}}$ GKOSN400/600/800/900 $=$ Represents $\mathrm{NH}_{3}$ heat treatment at different temperatures $\left({ }^{\circ} \mathrm{C}\right)$.

${ }^{\mathrm{c}}$ DETA $=$ Diethylentriamine $;{ }^{\mathrm{b}}$ PEHA $=$ Pentaethylenehexamine $;{ }^{\mathrm{c}} \mathrm{PEI}=$ Polyethylenimine.

In addition, to examine the effectiveness of the synthesized activated carbon by one-step activation process in $\mathrm{CO}_{2}$ capture at an ambience condition, a comparison study as have been tabulated in Table III is carried out. Referring to Table III, $\mathrm{CO}_{2}$ adsorption capacity of the synthesized activated carbon in this present work is equivalent or significantly higher compared to the published data. Comparing the virgin and surface-modified activated carbon, it shows that the $\mathrm{CO}_{2}$ uptake is improved for unmodified activated carbon. Surface area reduction of the modified-activated carbon weakly assists the physisorption process, and at the same time, chemisorbed amine compounds or nitrogen functionalities 
with the activated carbon enhances the basicity of the adsorbent. Nevertheless, the chemisorption process is ineffective at lower temperature and thus, causes poor $\mathrm{CO}_{2}$ adsorption capacity. The importance of the surface area in the physisorption process can be proved by comparing the sorption capacity of the prepared activated capacity in the study with the activated olive stone char [1]. Referring to the higher surface area possessed by the physically- $\mathrm{CO}_{2}$ activated olive stone char with the synthesized and the commercial adsorbent used in this study; it contributes to more adsorption capacity than the utilized activated carbons in this work. Yet, the surface area might not be the sole factor in influencing the $\mathrm{CO}_{2}$ adsorption on activated carbon [5]. Although chemically-treated activated carbon has the highest surface area in this comparative study, but the $\mathrm{CO}_{2}$ mass uptake is still relatively lower [2]. Thus, it can be concluded that one-step activation process without the carbonization or chemicals treatment is adequate enough to produce superior adsorbents.

\section{Isotherm Measurement}

The $\mathrm{CO}_{2}$ mass uptake onto the prepared and commercial activated carbon is evaluated by using the Langmuir isotherm. The Langmuir isotherm assumes that the adsorbent has finite capacity for the adsorbate, in which, no further adsorption can occur once the $\mathrm{CO}_{2}$ molecules already occupied the surface site. In other words, it indicates the existence of a monolayer adsorption of the adsorbate on the outer surface of adsorbents. Besides, the Langmuir isotherm assumes that the sorption sites are all identical and energetically equivalent. The Langmuir isotherm can be represented as shown in (2) [9].

$$
\frac{P}{V}=\frac{P}{V_{m}}+\frac{1}{K V_{m}}
$$

Based on (1), $P$ is the pressure (bar), $V$ and $V_{m}$ implies the total volume adsorbed and monolayer adsorption capacity $\left(\mathrm{cm}^{3} / \mathrm{g}\right)$, and $K$ indicates the Langmuir constant that is related to the adsorption energy (1/bar). The adsorption plot of $P / V$ against the saturated pressure of $\mathrm{CO}_{2}$ adsorbed gives a straight line with slope and intercept is $1 / V_{m}$ and $1 / K V_{m}$ respectively, as shown in Fig. 4.

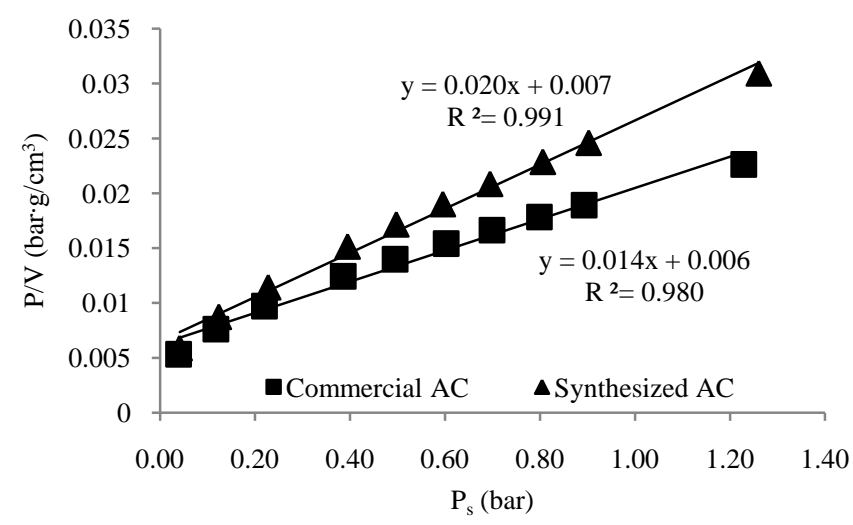

Fig. 4. Langmuir isotherm plot (AC = Activated Carbon).

The parameters that have been calculated from Langmuir isotherm model are summarized in Table IV. Based on Table $\mathrm{IV}$, the closer R-squared values towards unity suggest that
$\mathrm{CO}_{2}$ adsorption is well-described by the Langmuir equation.

TABLE IV: COMPARISON OF WEIGHT UPTAKE AT ROOM TEMPERATURE AND PRESSURE

\begin{tabular}{|l|l|l|}
\hline Samples & Parameters & Values \\
\hline \multirow{2}{*}{$\begin{array}{l}\text { Synthesized activated } \\
\text { carbon }\end{array}$} & $K[1 / \mathrm{bar}]$ & 3.09 \\
\cline { 2 - 3 } & $V_{m}\left[\mathrm{~cm}^{3} / \mathrm{g}\right]$ & 49.75 \\
\cline { 2 - 3 } & $R^{2}$ & 0.99 \\
\hline \multirow{2}{*}{$\begin{array}{l}\text { Commercial activated } \\
\text { carbon }\end{array}$} & $K[1 / \mathrm{bar}]$ & 2.29 \\
\cline { 2 - 3 } & $V_{m}\left[\mathrm{~cm}^{3} / \mathrm{g}\right]$ & 70.42 \\
\cline { 2 - 3 } & $R^{2}$ & 0.98 \\
\hline
\end{tabular}

\section{CONCLUSION}

In this study, exploitation of the lignocellulosic agricultural residues or by-product into low-cost adsorbents is attractive due to its abundance, eco-friendly properties, renewability, and economically feasible. In addition, the applicability of the solid adsorbent in acidic gas capture is significant, as it overcomes the problems caused by the amine scrubbing process that is the most acceptable technology used in industrial sector nowadays. The findings prove that the produced activated carbon from one-step $\mathrm{CO}_{2}$ activation process is microporous and capable in $\mathrm{CO}_{2}$ gas capture; with maximum sorption capacity to be roughly $8 \mathrm{wt} \%$. Also, the experimental data is well-fitted to the Langmuir isotherm, which can be verified by the closer regression value to unity.

\section{REFERENCES}

[1] M. G. Plaza et al., "Development of low-cost biomass-based adsorbents for post-combustion $\mathrm{CO}_{2}$ capture," Fuel, vol. 88, pp. 2442-2447, Dec. 2009.

[2] M. G. Plaza, C. Pevida, A. Arenillas, F. Rubiera, and J. J. Pis, " $\mathrm{CO}_{2}$ capture by adsorption with nitrogen enriched carbons," Fuel, vol. 86, pp. 2204-2212, Sept. 2007.

[3] M. Plaza et al., "Different approaches for the development of low-cost adsorbents," J. Environ. Eng., vol. 135, pp. 426-432, March 2009.

[4] A. C. Lua and J. Guo, "Preparation and characterization of activated carbons from oil-palm stones for gas-phase adsorption," Colloids Surf. A, vol. 179, pp. 151-162, Jan. 2001.

[5] A. Boonpoke, S. Chiarakorn, N. Laosiripojana, S. Towprayoon, and A Chidthaisong, "Synthesis of activated carbon and MCM-41 from bagasse and rice husk and their carbon dioxide adsorption capacity," $J$. Sustain. Energy Environ., vol. 2, pp. 77-81, Apr.-June 2011.

[6] J. Matos, C. Nahas, L. Rojas, and M. Rosales, "Texture properties and kinetic parameters associated to carbon materials obtained from sawdust of algarroba wood. 1. Application in phenol photodetoxification," Open Environ. Eng. J., vol. 4, pp. 1-10, March 2011.

[7] K. S. K. Reddy, A. A. Shoaibi, and C. Srinivasakannan, "Activated carbon from date palm seed: Process optimization using response surface methodology," Waste Biomass Valorization, vol. 3, pp. 149-156, June 2012.

[8] A. Allwar, "Characteristics of pore structures and surface chemistry of activated carbons by physisorption, FTIR and Boehm methods," IOSR J. Appl. Chem., vol. 2, pp. 9-15, Sept.-Oct. 2012.

[9] R. Parimalam, V. Raj, and P. Sivakumar, "Removal of acid green 25 from aqueous solution by adsorption," J. Chem., vol. 9, pp. 1683-1698, Oct. 2011

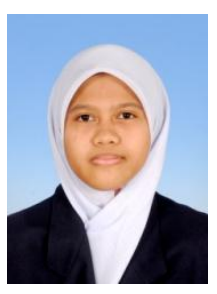

Nor A. Rashidi was born on July 25, 1988. The author's educational background is bachelor (Hons) of Chemical Engineering from Universiti Teknologi PETRONAS, Malaysia, 2010 and currently pursues her study in MSc in Chemical Engineering (Research mode) in the same university (2011-Present). She is now working as a research officer of Biomass Processing Group Universiti Teknologi Petronas. She had an industrial internship in BP Chemicals (M) Sdn. Bhd. in 2009. Her research interests include the material development, wastewater treatment, and gas capture and storage. 


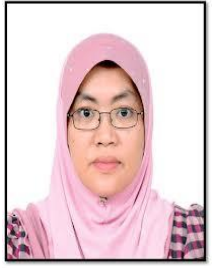

S. Yusup was born on November 11, 1969. The author has bachelor in Chemical Engineering degree from University of Leeds, United Kingdom in 1992, MSc in Chemical Engineering from University of Wales, United Kingdom, 1995, and received her Ph.D. in Chemical Engineering in 1998 from University of Bradford, United Kingdom. She is the Director of Mission Oriented Research (MOR Green Technology) since April 2011 and an associate professor in Chemical Engineering Department (2010-present), Universiti Teknologi Petronas. Her research area and specialization include bio-energy, material development, and biomass conversion.

Associate professor Yusup is registered with the Board of Engineers Malaysia (2001-present), a graduate member of the Institution of Engineers Malaysia (2002-present), and an associate member of the Institutional of Chemical Engineers since 2006. Associate professor Yusup is also a member of the Society of Chemical Engineers from 2012 to present.

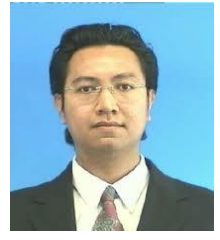

A. Borhan received his bachelor of Chemical Engineering (Hons) from University of Sheffield, United Kingdom and his MSc in Chemical Engineering from University of Wales. He is a lecturer at Chemical Engineering Department, Universiti Teknologi Petronas. His area of specialization includes membrane technology as well as wastewater treatment (environment). 